\title{
Post-Soviet Russian identity and its influence on European-Russian relations
}

\author{
A. Likhacheva ${ }^{1} \cdot$ I. Makarov $^{1} \cdot$ E. Makarova ${ }^{2}$
}

Received: 18 November 2014 / Accepted: 10 March 2015 / Published online: 20 March 2015

(C) The Author(s) 2015. This article is published with open access at Springerlink.com

\begin{abstract}
The current crisis between the EU and Russia is influenced by much more serious factors than political tensions over Ukraine or the US political agenda. We suppose that to some extent it has represented a consequence of the crisis of national identity in Russia during the post-Soviet period. And the ongoing crisis clearly reflects that unclear social, political and national identities allow some stakeholders to substitute an objective stimulus for sustainable cooperation with cultural and economic partners that have been historically close, i.e., Russia and European countries, by negative propaganda. The current perception of Europe and Europeans, which is widely shared
\end{abstract}

This paper is based to a significant extent on the report National Identity and the Future of Russia by Likhacheva A. and Makarov I., published by Valdai Discussion Club in 2014. URL: http://vid-1.rian.ru/ig/valdai/ Identity_eng.pdf. Accessed at March 18, 2015

This article is part of the Topical Collection on The Future of Europe, guest-edited by Markus Pausch

A. Likhacheva is a Research fellow, Centre for Comprehensive European and International Studies, Higher School of Economics

I. Makarov is a Senior research fellow, Centre for Comprehensive European and International Studies, Higher School of Economics and hold as $\mathrm{PhD}$ in Economics

E. Makarova is a lecturer, International Economics Department, Faculty of World Economy and International Affairs, Higher School of Economics

A. Likhacheva

ablikhacheva@gmail.com

1 Centre for Comprehensive European and International Studies, Higher School of Economics, Shabolovka 31B, r. 502, Moscow, Russia

2 International Economics Department, Faculty of World Economy and International Affairs, Higher School of Economics, Mytnaya str., 46/5, r. 306, Moscow, Russia by the majority of the Russian population, has switched from a thousand years of joint history, development and cultural enrichment to 'irreconcilable divergences'. This dramatic process develops both in the EU and Russia nowadays but in this paper we focus on the challenge to Russian identity, its roots and modern aspects. The analysis we provide within this paper demonstrates some fundamental preconditions of the political crisis between the EU and Russia that started in 2014, related to identity challenge rather than to international relations per se or value conflict. The concluding part of this paper is dedicated to a search for new approaches to identity policy that might be implemented in Russia and would positively influence a political dialogue between Europe and Russia by making it more predictable.

Keywords National identity · Post-Soviet identity · Europe-Russia relations $\cdot$ Individualism/collectivism dilemma

\section{Introduction}

The current crisis of European-Russian political relations, strongly supported by hysteria in the media of both sides, has mostly privatized the discourse between Europe and Russia [9]. Moreover, this crisis has almost blocked a perception of Russia as a unique but European country and RussianEuropean history as a joint history of millions of people, not only of states - both in Moscow and in Brussels. Meanwhile, passing from a level of political tensions to cultural and identity levels it would be hard to cross more than one thousand years of joint history, development and mutual cultural enrichment.

Developing the premise of I. Prizel that the foreign policy of any country is significantly influenced by a society's evolving notions of itself [15], we suppose that in addition to highlevel politics, a crucial factor of the European-Russian crisis is 
the problem of Russian identity search for itself. Large-scale disputes of European and national identities are also quite sharp but it has to be the objective of another research [6].

As for Russia, since the 1990s we have observed a situation where any identities in Russia (national, professional, social) have become weak without precedent. Then in the 2000s the majority of Russians became uninterested in politics, concentrated on their own micro-worlds and became inactive in public space. When the crisis between Russia and the West started in 2014 those people became only objects of media campaigns and their own stereotypes from the dramatic 1990s.

The fundamental assumption of our research is that weak national identity makes it susceptible to political propaganda and turns identity into an instrument of foreign policy instead of being its key driver and determinant. Conclusively, we assume that a current political crisis with Europe to some extent is a direct consequence of weak identities inside Russia during the post-Soviet period.

The term identity has to be defined. It has been used very broadly and has become vague as we can see in the critique of the term, for instance in Brubaker and Cooper [1]. The Russian academic tradition often replaces identity with the word self-consciousness [18], but those two concepts are not synonyms. Identity implies a sense of belonging to a certain group, a unity with its members. National identity in this case means the sense of belonging to a certain state or nation, which is shared with a group of people regardless of their country of citizenship [13]. Regarding the debate on identity in Russia the term "negative identity" is quite often used. Negative identity means a lack of positive values and need to build national consolidation based on an external threat according to Gudkov [5]. For the purpose of this paper, identity implies a wide range of values and personal characteristics that lead people to associate themselves with a particular nation or nation-state.

Speaking of the contribution of Asia and Europe in the Russian national identity, the paper assumes as given that we are carriers of an original culture, which nonetheless is European in nature. It is a culture based on an Eastern European language and art that is an outgrowth of three main traditions: Antiquity, Byzantium and Western Europe. At the same time, this country has a political and social culture that is unique, being neither European nor Asian, and is informed by its special history and geography.

\section{Historical identifications}

Russia's geographic position and special features of its development created a favourable ground for an active conflict between Westernizing and Slavophil ideologies. The issue of the Russian idea and historic path has been raised by statesmen and thinkers since the 12th century. (See, for instance, Instructions for Children by Vladimir Monomakh).
Over the past several centuries, a number of great minds have tried to find an answer to fundamental questions of Russia's development. They included A. S. Khomyakov ("Of the Old and the New"), R. A. Fadeev ("What Are We to Be: Russian Society in the Present and the Future"), P. Ya. Chaadaev ("Philosophical Letters"), V. S. Solovyev ("L'idée russe"), N. A. Berdyaev ("Russia's Fate"), A. M. Maslennikov ("The Ideology of The Imperial Power in Russia"), L. P. Karsavin ("East, West and the Russian Idea"), Serafim (Sobolev) ("Russian Ideology") and, finally, the last Russian genius, A. I. Solzhenitsyn ("How Are We to Improve Russia), among others. For a review of thinkers seeking an answer to what the Russian idea should be like see an anthology by Yakunin [20].

As an heir to Byzantium with its special spirituality Russia has been viewed within an ecclesiastical concept. The ecclesiastical idea assumes a communal spirituality and, consequently, the notion of human brotherhood, which in the case of Russia entails communal brotherhood. This Byzantine Christian tradition has been seen as anti-Western, even though at the time when Russia adopted Christianity Byzantium was the most advanced area of Christian Europe. The proponents of the ecclesiastical vision saw the West as the main, uncompromising foe, both ideologically and politically. The ecclesiastical vision entails a return to the concept of "Orthodoxy, Autocracy and Nationality" (or, in some other form, "Spirituality, Statehood and Ecclesiastic Idea") as a basic building block of national identity. ${ }^{1}$ Since this strategy and means of achieving it points to the past and to a lack of a stable connection to reality, the use of the ecclesiastic vision in laying ideological foundations for the country's development may prove difficult.

Supporters of the Russian Doctrine believe that the "Global Russian Project" should be advanced on the basis of dynamic conservatism. They envision room for reforming the existing state and society, but only in order to achieve the main goal: to preserve traditions. ${ }^{2}$

Keeping in mind a certain utopian quality entailed in the creation of a proto-state, and the on-going shift in society away from the idea of the Russian Civilization in the way the concept's authors see it, it does not seem that it will be able to play a significant role in developing the domestic and foreign policy of the country.

Adherents to the Neo-Imperial or Neo-Soviet concept see the resurrection of the old Empire or the building of a new one as the main goal of Russia's existence. This school, along with more moderate calls to take account of the "unconscious Sovietism" that survives in a large portion of the population, includes radical appeals to create an "unconventional Empire, a world of worlds, or the USSR-II" [7].

\footnotetext{
${ }^{1}$ Russian Doctrine (Sergy's Project) is presented at http://www. velikoross.ru/doktrina/ Accessed on March 5, 2015

${ }^{2}$ Ibid
} 
The Nationalist and Ultra-Nationalist school sees the key to success in recreating the Empire around the Russian nation. The Neo-Imperial movement wants the Great Empire to be restored mainly by force and wants the nation to be mobilized against its enemies who threaten it from all sides. In other words, they want to embark on the same path that a quarter of a century ago doomed the USSR. This school of thought is unrealistic, but it should not be dismissed out of hand. It is backed by a powerful, centuries-old idea, which was the core of the nation and the state, i.e., defence against the outside threat. Finally, at a time when other sources of strength of the nation, such as spiritual and technological ones, are stagnating and even decaying, reliance on military power may have an appeal to many people.

The Liberal Westernizing Movement, whose supporters want Russia to adopt the democratic model of development primarily oriented toward European nations, presents a sharp contrast to the above-mentioned concepts. The crises affecting Western nations have greatly reduced the appeal of this school. Moreover, one of the weaknesses of the Liberal Westernizing School is that they embrace an ideal without taking account of the situation on the ground, the state of society and the people, who have a very limited experience of democratic development and have been traumatized by 20 th century history.

The Eurasian concept rejects both Sovietism and liberal Westernization as suitable for Russia, stressing instead that the country is an "independent and self-contained civilization". 3

The range of ideological currents whose goal is to define Russia's path and identity is not limited to the abovementioned concepts, but they give a clear sense of the difficulty of making the national choice. The range of choices Russia can make in its attempt to define itself is extremely broad, including [11]:

- integration into the European civilization or preservation of the special Russian civilization;

- empire or nation-state;

- relative isolation or full openness;

- liberalism or paternalism;

- individualism or collectivism;

- mobilization or modernization;

- Political or Imperial nation.

The two decades that have passed since the collapse of the Soviet Union have precluded a revival of the Soviet identity. The Russian identity has started to be recreated in the mass consciousness but it has not become strong enough and has not been reflected in a tangible strategy of the country's development. Russia finds itself in a difficult position. After

\footnotetext{
${ }_{3}^{3}$ See more about Eurasia Political Party at http://eurasia.com.ru/ basicprin.html. Accessed on March 5, 2015
}

1917, the Soviet identity was systematically imposed while the pre-Soviet one was deliberately destroyed. The last remnants of the Soviet identity are dying out, whereas the preSoviet identity has not been restored. Nor can it ever be fully restored.

\section{Modern identity challenge}

Russian society is fractured and its ideological, religious and ethnic fault lines continue to multiply. The elites have been active participants in this fracturing. The state has a negative image that is only becoming worse: we have endemic corruption, disrespect for human rights and widespread social vulnerability in place of a social safety net.

Over the past 20 years, the values of our citizens have changed dramatically, and not for the better. Soviet communism destroyed the Christian and universal religious morality. The Soviet morality and ideology were destroyed in the 1990s. No new morality and ideology, which could have been a foundation for building a competitive new Russia, has emerged. This is why traditional religions in Russia are so important in order to introduce moral norms in society. Attempts by churches to compensate the numerous social failings in one fell swoop have had the opposite effect: interest for religion has been waning after spiking in the early $2000 \mathrm{~s}$.

Among the values of today's Russians material well-being and consumption take first place - 55\% in 2006 compared to $31 \%$ in 1986 . Hereinafter in this section data on Russian polls are cited from Salmina [17]. Decades of shortages and then conspicuous consumption by the elites, as well as the promotion of upscale consumption by the mass media. Given the highly unequal income distribution, this leads to an even greater fragmentation of society and growth of social tensions.

An entire non-patriotic generation has been raised, who only marginally associate themselves with their country. They do not know its history and are not prepared to build their future here. The sense of community shared with other citizens of the country has been lost. The proportion of those who want to be useful to society has declined fourfold in the period of 1986-2006 from 26 to $6 \%$.

Even the importance of family and children has declined. While in $1986,{ }^{4}$ before the onset of major social and economic reforms, family and marriage were in first place among the values of the Russian people, at $60 \%$, followed by children at $55 \%$, today the importance of family and children has declined, even though it remains high, at 53 and $45 \%$, respectively.

\footnotetext{
${ }^{4}$ Results from 1986 are from a poll conducted by the Institute of Sociology of the Russian Academy of Sciences under the direction of Prof. Levykin (a sample of 4,400 participants). Results from 2006 are from a poll by TsESSI (a sample of 1,200), conducted using the same methodology.
} 
The attitude towards work has changed as well. In the Soviet era work was viewed as a source of respect, social status and self-realization; today, the majority sees work as a source of material well-being. On the other hand, today, unlike the Soviet era, it actually can provide it. Meanwhile, the importance of an "interesting job" declined from 41 to $29 \%$, while "respect of others" went from 27 to $17 \%$. In effect, we have seen abstract values being replaced by material ones [4].

The scale that measures determinants of personal success has also changed noticeably. The importance of work has declined, from 74 to $52 \%$, while the share of Russians who believe that success depends on luck has increased, from $7 \%$ in 1986 to $30 \%$ in $2006 .{ }^{56}$ This reflects important aspects of today's life, such as a lack of predictability and clannish closeness of the elites.

Professionals and the educated portion of the elite have lost hope to transform the government quickly and have seen the full depth of corruption, nepotism and lack of professionalism that prevails there. They have started to criticize not only the ruling class but society as a whole. They insist - correctly at times - that Russians are antisocial and fragmented, and instead of acting as citizens they act as pathologically profitmaximizing individualists. But they ignore factors that created this: the highly controversial Soviet period, then the collapse of the state and the turmoil and privations of the 1990s, and then a period of tranquillity, which has now been transformed into apathy.

Nevertheless, people have not lost their ability to assess the situation objectively, which is evidenced by the obscenely low level of trust for all state entities and structures. The only exception is the President, whose absolute trust has fluctuated in the $60-70 \%$ range in recent years, and conservative institutions, such as the Church and the Military, who are trusted by around four out of every ten Russians [4, 16].

During the difficult 1990s, people developed another important quality, self-reliance. Just as they had done many times in their history, the Russian people proved their extraordinary ability to survive. But people are tired of constantly struggling to survive all by themselves. The accumulated exhaustion has logically translated into the desire to have a high level of social protection, stoking the age-long affinity for paternalism.

People are able to assess the true extent of the natural wealth of the country while also gauging the extent of social inequality, giving rise to an emotional desire for more social

\footnotetext{
5 Today's Russians value much less than their Soviet counterparts such qualities as honesty and decency (63\% in 1986 vs. $41 \%$ in 2006), compassion and goodness (57\% vs. $27 \%$ ), mutual understanding and mutual assistance (53\% vs. $27 \%$ ), responsibility ( $46 \%$ vs. $32 \%$ ), principled positions ( $22 \%$ vs. $14 \%$ ) and unselfishness ( $20 \%$ vs. $10 \%)$.

${ }^{6}$ Positive changes have been in the higher value ascribed to individualistic leadership qualities, such as determination in achieving goals $(27 \%$ vs. $37 \%$ ), abilities and talents ( $15 \%$ vs. $32 \%$ ), initiative ( $21 \%$ vs. $25 \%)$, ability to compromise, flexibility ( $4 \%$ vs. $20 \%$ ) and leadership (9\% vs. $16 \%)$.
}

protection with an ironclad logic: income from natural resources should be divided more equitably.

It should be noted that material well-being (along with good health, which is valued by $33 \%$ ) is followed on the scale of social values by the dream of living in a more just and rationally structured society (33\%). This is effectively a demand for equal opportunity to realize one's talents and equality before the law.

Let us stress it one more time: people in Russia have not demanded direct financial support. Some outrageously underfunded professions sometimes make this demand. But ordinary people have deserved Russia's wealth to be channelled to equalize opportunities by not lowering the plank but by raising it; i.e., they do not want the oligarchs' kids to be sent to a village school, but to raise the level of education obtained at village schools to that of rich urban ones. Above all, such demands concern health care and education, i.e., the physical and mental well-being of the nation.

Thus, despite objective problems and various dangers, we should not yet lose hope with regard to Russian society. The difficult situation as far as its values and norms is concerned at the everyday, social and state levels has nothing to do with the question of national identity. It merely describes the current state of affairs in Russia.

\section{Nation state or empire}

Academic attempts to separate the issue of identity and nation into two groups, civic and ethnic, proved to be a failure in Russia. An ethnic division is a senseless and dangerous Utopia. An attempt to formulate a national identity through ethnicity and religion goes against the grain of the history of the Russian civilization. It may temporarily unite a portion of the population but it would undermine the very foundations of Russian society and the state. I.A. Bunin ${ }^{7}$ wrote: "... the people are like lumber. It can be fashioned into an icon or a stick, depending on who works this piece of lumber, St. Sergius of Radonezh or Yemelian Pugachev" [2]. Any time society yields to chauvinism, be it Russian nationalism or the nationalism of smaller groups, it is a path leading to suicide.

It is too early, to say the least, to discuss the emergence of a civic nation in a country that twice in the past 100 years effected a revolutionary change of its political system and economic model and failed to build a law-based state. In Russia, the historically dominant culture has been the Russian culture. Russia has its minorities and they will always be there, but the trauma of the 20th century, with its criminal policy with regard to other ethnic groups (it would suffice to mention persecution and exile of entire nations based on their bloodlines and the division of the country into 15 national republics,

\footnotetext{
${ }^{7}$ Outstanding Russian writer, winner of the Nobel Prize for Literature
} 
which then underpinned their demand for independence), must not be carried over into the 21st century. The Russian national identity must be built based on the principle of a common cultural space with bright ethnic additions that serve to enrich the main culture. The most obvious example of this is the coexistence of sauerkraut, salted herring, shish kebab and pilaf on our holiday tables.

At the moment there is no option besides admitting that Russia is neither a nation state nor an empire. In the long run, Russia could be some hybrid form of a civic and culture-based nation. The connections which lie in the cultural space are codified in the great Russian literature, music, visual arts, architecture and cinema, the latter being the strongest melting pot for all who see themselves as connected to the Russian Federation. The original Russian culture emerged as a result of many centuries of intertwining great cultures, first the Antiquity and Byzantium, as a result of an invasion - the Tatar-Mongol culture and, finally, the brilliant Western European culture of the modern age.

In the course of this complex symbiosis, the internationally recognized Russian culture was formed in the 19th century, taking its rightful place in the world and continuing into the 20 th century. As an amalgam of different elements can undergo chemical reactions and acquire new and improved qualities compared to the original components, so the Russian culture was able not only to combine disparate tradition but also to enrich them and to raise its own structure based on that foundation. The result has been the emergence of the original Russian nation and the Russian identity, which existed in the Russian Empire. Under massive pressure, it was partially replaced by the Soviet identity that endured for less than 100 years. Naturally, our unique culture has been lost, but the connection to it has been weakened. It must be strengthened again and bolstered by new works. When it is restored, it will in itself become the source of inspiration and enthusiasm and provide moral support for the people, society and the state.

Naturally, the Russian identity must be discussed in modern terms, understanding not only what the Russian culture and history have to offer, but also what a modern world demand is. Most heritage projects, either it is the heritage of the Byzantine Empire or the Soviet Union, reek of mothballs. They are invariably backward looking and have no power to rally the people for long time.

The key question that needs to be answered before discussing identity is the question of its carrier. Are we talking about the country (Russia's path) or its citizens (and what makes one a Russian in the first place)? Traditionally the Russian political thought defined the state as the main subject of national identity and has been concentrated on 'historic choice'. But in reality, the subject of national identity is not a state but its citizen. And a citizenship implies rights and responsibilities. Nowadays attitudes of Russians to both of them are quite foggy.

\section{From population to society}

For most Russians economic and social rights definitely prevail over the political ones. Those who give enough credit to political rights mostly favour the so-called 'passive rights', i.e., freedom of speech and conscience. Here the focus is on the freedom from direct responsibility for the realization of the right rather than on the freedom of participation. Therefore, the majority perceives political freedom as 'freedom from political participation rather than freedom of political participation' [12].

At the beginning it should be stated that most Russians are not interested in politics. This is especially true of the youth. In 2008 almost two thirds of the population had 'no idea whatsoever what political regime there is in the country and what regime would be desirable' [4]. In accordance with 2010 estimates, $40 \%$ of the population are absolutely uninterested in politics or they find it difficult to formulate their preferences [19]. The mistrust in the main branches and institutions of power (the President being the only exception) is based on the objective evaluation of their performance and thus does not inspire any interest in politics either. For many people formally having political preferences the 'label' without any explanation of its implications limits them.

Speaking about the attitudes to freedom and democracy, it would be of interest to point out a curious contradiction. The notion of human rights (personal freedoms) ranks higher than 'collective freedom', i.e., democracy [16]. At the same time, the majority of Russians (54\%) are convinced that collectivism, the notion of community and tough government regulation are more typical of Russians and better suit the national culture than Western-type individualism and liberalism [8]. It is likely that here we once again face the clash of notions and true preferences: the direct question of what is more valuable to you elicits one answer, while the answer to the question on society in general contains generally accepted attitudes rather than personal opinions.

Disappointment and apathy are the words that describe the majority's attitude to politics in general and to the existing power institutions' performance in particular. This civil amorphousness cannot be exclusively attributed to the crisis of today's political system devoid of any comprehensible value paradigm.

No matter how sad it may sound, so far Russians have proved to be asocial. For the vast majority the circle of contacts, interconnectedness and personal responsibility is limited by the family and closest friends, mostly childhood ones. Only $50 \%$ believe they can anyhow influence the situation even at work [4]. The maximum involvement in social institutions (meagre $2 \%$ ) falls on the participation in school parents' associations, all other forms of association (sports societies, religious communities, associations of fellow-countrymen, etc.) account for $0.5-1.9 \%$, while $90 \%$ of the population do not 
belong to any NGO or movement [4]. Besides, Russians do not tend to visit public spaces $[4,10]$ : on the one hand, this is due to the low level of income that prevents people from spending on leisure; on the other hand, this is due to the limited circle of contacts and reluctance to go beyond it. However, this state of things is an obvious outcome of the social and economic 'trauma' of the 1990s: in the Soviet era in the conditions of closed society with limited leisure infrastructure cinemas performed a significant compensatory function. Young people went to the cinema almost weekly and on average, taking into account new born and senile people, a Soviet person went to the cinema 18-20 times a year [3]. Concurrently there was a reaction to the induced involvement in public life over 70 years of the Soviet era (subbotnik, ${ }^{8}$ participation in demonstrations, public committees, etc.). This kind of asocial tradition is now being translated by senior generations to their children.

The combination of the abovementioned features leads to the fact that Russians tend to be massively inactive in public spaces, they lack environment for discussing their own political requirements and eventually do not articulate any political demand.

There is no community - there is an illusion from Internet forums. In this paper we focus on the most promising option to strengthen an identity and thus - to partially extract bilateral and multilateral relations from quickly evolving political conjuncture keeping some cultural and identity foundation for an on-going dialogue.

If we move a bit above a Leviathan concept of a state we must admit that it is very important role is to create a sphere for human interaction where smaller identities can be formed and to nudge people toward each other in order to make sure those threads start connecting them. It should send signals and provide symbols to society, which would help people come together. It should also seek and develop points where this coming together can occur, above all, in the Russian language and culture. It must refrain completely from sending signals and imposing symbols which would divide various social, ethnic and religious groups.

The role of society and its intellectual elites is to use this sphere and not turn away from it. They should formulate ideas which arise in the course of civic discussion, the best ones of which the state should then implement.

Russian society is deeply divided. Individuals are rooted in their families, friends and the home and nothing and no one else matters. There are very few strong identities. The religious and ethnic identity is static and strictly defined. These identities may be useful as engines of creative activity, but their role will always be limited. At the same time, professional, civic and even hobby-based identities remain very vague.

\footnotetext{
$\overline{{ }^{8} \text { Large-scale compulsory area cleanings on Saturdays }}$
}

A project that could take the country out of its depression could be to create as many active identities as possible. This can be achieved if we build platforms for active people to engage in interactions. The most obvious examples of such platforms are local self-government and independent organizations of citizens, or non-government organizations.

Professional identities can be revived by developing professional associations whose purpose is to support professional debates (but not trade unions which in their current form function exclusively as means of distributing social goods). Such platforms should be completely unbureaucratized and must function without the intermediation of any officials, except as individuals.

But the main task remains to promote respect for work. We must pay special attention to occupations that are crucially important for today's Russia, i.e., teachers and medics. Those two professional fields were severely damaged in the 1990s, even though they are very strongly united by professional ethics, share common values and speak the same language in every corner of the country.

The restoration of university student associations is an important task as well, not as social groups but of students as cultural actors. We must revive the nearly forgotten students' traditions. Young people are the engine of the country's development. They should be brought together into a single creative force, which will have a great potential, one that has not been engaged today.

Nor should we neglect the powerful and system-building role of public schools in socializing the population. It remains the only remaining state institution which all Russians attend. Both students and parents are socialized, either voluntarily or forcibly. Parents-teachers committees are today the area where most Russian are socially active, since around $2 \%$ of citizens participate in such committees [4]. Rural schools play a particularly important role. They are often not just a place where kids get their education but the main cultural centre bringing together all generations.

First steps have already been made in developing the schools' potential for socialization. A recently adopted set of federal educational standards (which in effect reflect society's demands on the school system) stress that every student must undertake social projects. All we need is to engage this component.

The society has to develop platforms for leisure activities, setting up clubs for people with such hobbies as music, cinema, local history, the environment, etc. and developing amateur athletics - all those activities are not only about particular interest - they are about membership, co-participation - being a part of a group, not of a crowd. It is of great importance to develop urban spaces and to transform cities, which are home for a growing proportion of Russians, into a friendly environment promoting human socialization rather than pushing people away and toward their television screens and computers. 
The proposed ideas aim to revive creative collectivism and, especially, solidarity which has always been a special strength of the Russian people and which has all but disappeared. Except now it will be a new kind of collectivism, different from the one that was cultivated in the Soviet Union. That one was artificial and its result was failure. It will not be an imposed collectivism in which the weak keep the strong back. It will be a voluntary and mutually beneficial collectivism, which will allow the strong to join their efforts and thus become, with active support from the state, even stronger, pulling up the weak along the way. It will be a collectivism which will arise due to the need for self-realization of the individual - who is always motivated, be the desire to serve - and therefore represents the highest form of individualism.

\section{Education}

The area where Russians are still the most proactive and involved is the education system. The forms of this participation vary and are not always perfect but as we mentioned above at least school is a unique institution in Russia which the whole population passes through and even two times - as a pupil and as a parent of a pupil.

Meanwhile all participants of the educational system are in need of retraining, while reforming the system, as a whole should be a national priority. Above all, it is because there is a fundamentally new demand on education, which is different from the one that existed in the Soviet Union - and which did not, in reality, exist at all in the 1990s. There is a need for schools to develop an individual and for universities to form a professional. The most important skill in today's world is the ability to learn. It is the only skill that can provide decent living over the course of a lifetime.

Russia has lost the competition to Asian countries in industrial labour, while competition with developed countries in creative spheres and in the service sector is intensifying. There is no room for a lack of professionalism and low productivity. The new technology-based system leaves us no alternative but to put the highest value on the creative, educated individual as far as society and the state are concerned.

But the educational system must not be regarded as solely a production line for a competitive labour force. The teaching profession remains the main guardian of national values. It is in school that a child is first exposed to the Russian literature and the Russian and world history. Primary school lays the foundations for the main values and forms the character, too. All ratings show that our kids finish primary school at the top compared to the rest of the world. But this enormous potential is negated by the failure of the middle school and the rest is either sustained or wasted at high school and in secondary education.
Improvements in the educational system are a long and multi-directional process. Its main principles include regionalization of public spending for education, improved training both for teachers and administrators, university reform aimed at making them more competitive, etc. [14].

This is the briefest possible list, and each of the abovementioned points will only be able to meet the demand of the educational process when it is developed further and expanded, and supported by substantial investments. And we must never forget that education is the main source of national inspiration.

\section{Conclusions}

Our analysis allows us to reveal serious problems with identity (on different levels from national to professional) inside Russia and it is getting obvious that those constraints have influenced both Russian internal and foreign policy. Moreover, several gaps in national identity space and the current development of negative identity form an additional obstacle to solving the Russia-EU crisis.

The most promising options to overcome this heritage are the socialization of people and education. Development of those tracks will contribute to a positive reset of the European-Russian dialogue even without particular EU or Russian efforts - because it will allow people and communities both in the EU and Russia to turn to objective and mutual interests, to enrich each other in research, culture, creativity, business. Finally it will make these mutual relations more predictable. Both in Europe and in Russia exist a clear understanding that a successful promotion of education and a feeling of co-participation are key factors that determine international competitiveness in the 21 st century. So even despite strong political controversies, these objective factors will give a common ground for Russia and Europe. Otherwise the crisis both for Russia and Europe will be extremely tough.

As far as interconnections between Europe and Russia are much stronger than gas and food deliveries (which is mostly a tabooed topic for last year), a turn to respectful historic and cultural heritage, a pass from political and interstate level of a dialogue to a personal and community ones will provide a necessary playground for a real dialogue of the 21 st century. This dialogue admits mutual respect, a right for mistakes in the past and in the present and opportunities to correct them i.e., a historic model of relations that have existed for hundreds of years on the European continent.

Open Access This article is distributed under the terms of the Creative Commons Attribution License which permits any use, distribution, and reproduction in any medium, provided the original author(s) and the source are credited. 


\section{References}

1. Brubaker R, Cooper F (2000) Beyond "identity". Theory Soc 29(1):1-47

2. Bunin I A Cursed Days. Quoted by the 1991 Moscow edition, p. 54

3. Dondurey D (2005) Film Distribution: Entertainment Industry Gem // Otechestvennye Zapiski № 4 (25)

4. Gudkov L, Dubin B, Zorkaya N (2008) Post Soviet person and civil society [Postsovetskiy chelovek i grazhdanskoe obshchestvo]. Moscow School of Political Studies

5. Gudkov L On enemies, propaganda technologies and negative identities. Open Russia, October 21, 2014. https://openrussia.org/ post/view/507/ Accessed 5 March 2015

6. Jenkins R (2008) The ambiguity of Europe: 'Identity crisis' or 'situation normal'? Eur Soc 10(2):153-176

7. Kalashnikov M (2003) Onward, to the USSR. Moscow, Yauza

8. Karaganov S (2013) Authoritarian Rule, Democracy, 21st Century // Nezavisimaya Gazeta

9. Karaganov S (2014) Europe and Russia: preventing a new cold war. Russia in Global Affairs

10. Kashirskih O N (2012) Russians' Political Preferences Under the 'Transit Dilemma' Conditions. Accessed under hse.ru/data/2012/ 10/09/1247022308/Политические преференции россиян в условиях дилеммы транзита.doc
11. Kortunov SV (2009) National Identity: Comprehension of sense [Natzionalnaya identichnost: postizhenie smysla]. Aspect press, Moscow

12. Likhacheva A (2013) One democracy or another ...// Nezavisimaya gazeta scenarios, September 24, 2013

13. Likhacheva A, Makarov I (2014) National Identity and the future of Russia. M. Valdai Discussion Club

14. Lubimov L (2013) Russian School - education of public spirit. Voporsi Obrazovaniya, № 1. pp 278-300

15. Prizel I (1998) National identity and foreign policy: nationalism and leadership in: Poland, Russia and Ukraine, Vol. 103. Cambridge University Press

16. Rogov K (2012) Political cycles of post-Soviet transit [Poltiticheskie tsikly postsovetskogo tranzita]. Pro et contra 16:4-5

17. Salmina A (2013) From homo soveticus to homo economicus // Nezavisimaya gazeta scenarios. September 24

18. Tishkov VA (2013) Russian people: history and a sense of national self-consciousness, [Rossiysky narod: istoria i smysl natsionalnogo samosoznania]. Nauka, St. Petersburg

19. WCIOM Express (2010) Russians’ Idea-Political Preferences. №21

20. Yakunin V.I. et. Al (eds.) (2012) National idea of Russia [Natzionalnaya idea Rossii], vol 6. Moscow, Nauchnyy Ekspret. 